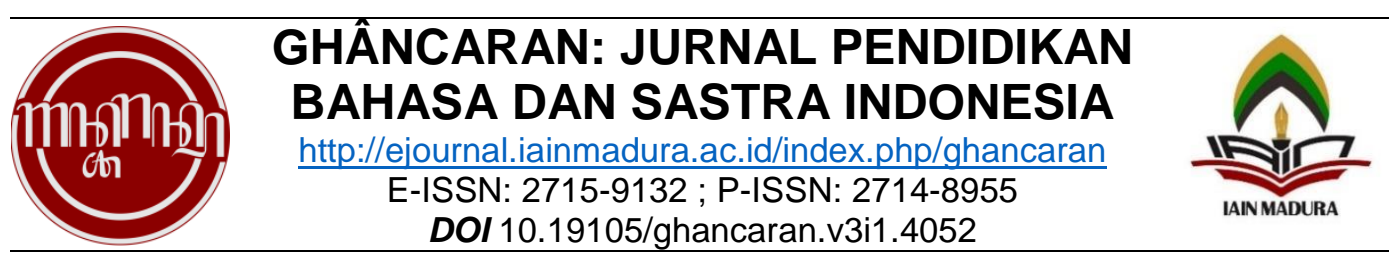

\title{
Analisis Kesalahan Berbahasa Bidang Morfologi dalam Laporan Isu Hoaks Corona Virus oleh KOMINFO
}

\author{
Agus Tika Dwi Savira*, Sarifah Firda Arindita Nafarin**, Siti Nur Fa'izah*** \\ * Tadris Bahasa Indonesia, UIN Raden Mas Said Surakarta \\ ** Tadris Bahasa Indonesia, UIN Raden Mas Said Surakarta \\ *** Tadris Bahasa Indonesia, UIN Raden Mas Said Surakarta \\ Alamat surel: agustikadwi1234@gmail.com, sarifahfirda@gmail.com, \\ izahidr4@gmail.com
}

\begin{tabular}{ll}
\hline \hline & Abstract \\
\hline Keywords: & This research aims to describe the language errors in the field of \\
Corona Virus; & morphology, especially in the affixation process and its justification \\
Language & in the Issue Hoax Corona Virus Report by KOMINFO. The benefit \\
Mistakes; & of research is to provide insight and knowledge for readers on the \\
Affixation. & use of good and correct Indonesian in the context of writing. \\
& Affixation errors cannot be ignored, because at first glance the error \\
& is not visible, but it is very important considering that many readers \\
& are interested in explaining the reasons why the corona virus or \\
& covid-19 hoax issues. This approach uses descriptive qualitative \\
& research methods with data collection techniques refer to, record \\
& and take samples. The method used to analyze the data is the \\
& aggregate method. The results of this study indicate that there are \\
& still many language errors even repeatedly in the report on the \\
& issue of corona virus hoaks by KOMINFO. Errors in this study \\
& include 8 prefix errors, 0 infix errors, 18 suffix errors and 12 confix \\
& errors. This research aims to describe the language errors in the \\
& field of morphology, especially in the affixation process and its \\
& justification in the Issue Hoax Corona Virus Report by KOMINFO. \\
& This approach uses descriptive qualitative research methods with \\
& data collection techniques refer to, record and take samples. The \\
& method used to analyze the data is the aggregate method. The \\
& results of this study indicate that there are still many language \\
& errors even repeatedly in the report on the issue of corona virus \\
& hoaks by KOMINFO. Errors in this study include 8 prefix errors, 0 \\
infix errors, 18 suffix errors and 12 confix errors. \\
\hline \hline
\end{tabular}




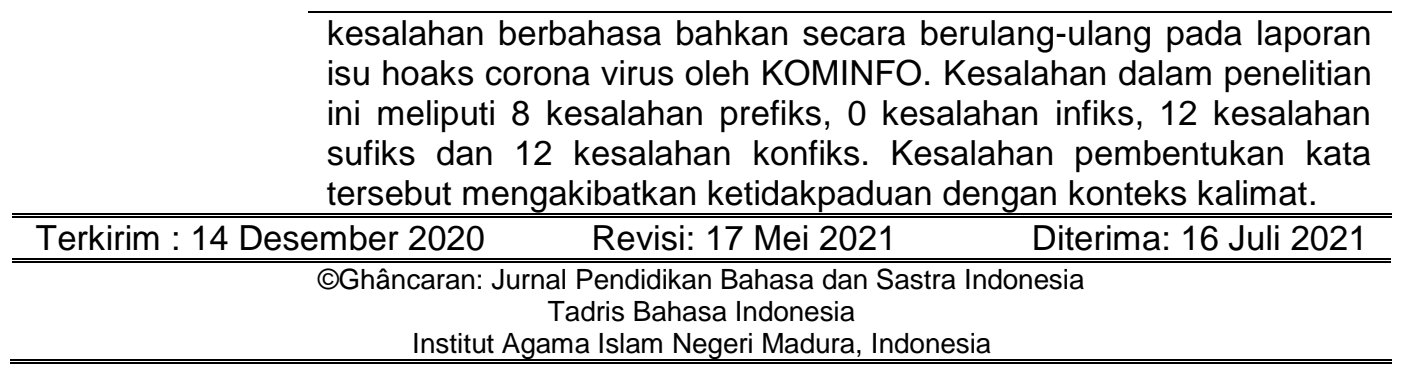

\section{PENDAHULUAN}

Pada saat melakukan kegiatan berkomunikasi dalam kehidupan sehari-hari, seseorang pasti memerlukan bahasa. Oleh karena itu, bahasa memiliki peran penting di dalam kehidupan, yaitu sebagai alat penyampaian pikiran, gagasan, konsep ataupun perasaan karena pada umumnya bahasa digunakan sebagai alat komunikasi (Pinem \& Lubis, 2017). Ketika seseorang berkomunikasi dengan orang lain, hendaknya menggunakan bahasa yang baik dan benar agar maksud dari pembicaraan dapat tersampaikan. Oleh sebab itu, Priyono (2012) menyampaikan bahwa pengguna bahasa terutama bahasa kita sendiri, yaitu bahasa Indonesia harus selalu diperkaya dengan cara mempelajarinya terus menerus dari lahir sampai meninggal. Namun, tidak dapat dipungkiri, ternyata masih banyak kesalahan berbahasa yang kita jumpai hingga saat ini.

Kesalahan berbahasa biasanya disebabkan oleh kurangnya penguasaan akan bahasa sehingga bahasa yang dimiliki terbatas. Menurut Nurwicaksono \& Amalia (2018) kesalahan berbahasa adalah penggunaan bahasa yang menyimpang dari kaidah kebahasaan yang berlaku dalam suatu bahasa. Kaidah yang sudah ditetapkan kadang dilanggar dengan keyakinan bahasa yang dibuat oleh suatu individu atau kelompok yang sudah biasa dengan ketetapan bahasa yang ada. Hal tersebut dapat terjadi karena bahasa merupakan sistem lambang bunyi arbiter yang digunakan oleh para anggota kelompok sosial untuk bekerja sama, berkomunikasi, dan mengidentifikasi diri (Verawati \& Mulyadi, 2019). Hal ini yang membuat beberapa orang atau kelompok terbiasa menggunakan aturan kebahasaan yang diciptakan oleh mereka sendiri. Padahal, terkadang hal tersebut kemungkinan salah. Agar hal ini tidak banyak terjadi, maka diperlukan sebuah analisis kesalahan berbahasa.

Analisis kesalahan berbahasa dapat dipandang sebagai suatu rangkaian aktivitas dalam mengumpulkan, menjelaskan, dan mengevaluasi kesalahan dalam berbahasa (Johan, 2018). Berbagai kesalahan berbahasa yang ada akan dijelaskan kemudian diluruskan agar tidak terjadi adanya kesalahan serupa. Hal ini bertujuan untuk memperbaiki berbagai macam kesalahan dalam berbahasa agar tidak ada lagi 
penyimpangan dari kaidah kebahasaan yang berlaku. Oleh karena itu, mempelajari suatu bahasa termasuk hal yang penting.

Bahasa sebagai alat komunikasi memiliki keterkaitan dengan morfologi karena morfologi termasuk ilmu yang mempelajari hal tersebut. Morfologi merupakan salah satu cabang linguistik yang mempelajari tentang kata dan pembentukannya (Malik \& Fatimah, 2017). Oleh sebab itu, sebelum membuat kalimat yang baik kita harus memperhatikan pembentukan kata yang baik pula. Menurut Sintia, Sudiana, \& Nurjaya (2019) kalimat yang baik dapat memunculkan pemikiran yang baik oleh si pendengar, dan si penyampai pun tidak perlu menjelaskan apa yang disampaikan. Hal ini selaras dengan pendapat Permatasari (2013) bahwa bahasa akan mudah dipahami jika disampaikan dengan bahasa yang tepat pula, lugas, dan mudah diterima oleh mitra tutur.

Kesalahan morfologi yang sering terjadi dan banyak dijumpai adalah proses afiksasi. Hal ini dikarenakan masih banyak orang yang menganggap kesalahan proses afiksasi merupakan hal yang biasa. Proses afikasi meliputi prefiks, infiks, sufiks, dan konfiks. Afiks merupakan bentuk linguistik yang keberadaannya hanya untuk melekatkan diri pada bentuk-bentuk lain, sehingga mampu menimbulkan makna baru terhadap bentuk-bentuk yang didekatinya (Astuti, 2012). Pada saat terjadinya kesalahan proses afiksasi, maka dapat menimbulkan perbedaan makna dari kalimat yang dimaksud. Prefiks merupakan pembubuhan afiks di awal bentuk kata dasar, infiks di tengah bentuk kata dasar, sufiks di akhir bentuk kata dasar, sedangkan konfiks ialah pembubuhan afiks gabungan (Chaer, 2012).

Kesalahan proses afiksasi masih banyak dijumpai bahkan dalam bentuk laporan sekalipun. Padahal, dalam membuat laporan berarti kita harus memperhatikan berbagai aspek kebahasaan agar tidak ada kesalahan sehingga informasi tersebut dapat diterima semua orang. Hal tersebut dikarenakan laporan merupakan suatu penyampaian berita, keterangan atau pemberitahuan secara lisan dan tulisan. Salah satu laporan yang coba diteliti kesalahan morfologinya di sini adalah Laporan Isu Hoaks Corona Virus oleh Kementerian Komunikasi dan Informatika (KOMINFO).

Laporan Isu Hoaks Corona Virus oleh KOMINFO berisikan berbagai macam kabar hoaks yang beredar di media sosial. Hal ini dikarenakan maraknya kasus virus baru yang menyerang berbagai belahan dunia mulai akhir tahun 2019. Virus tersebut dinamakan virus corona atau covid-19. Covid-19 merupakan virus RNA strain tunggal positif yang menginfeksi saluran pernapasan (Yuliana, 2020). Kemunculan virus ini 
membuat orang-orang mengalami kepanikan, sehingga dengan mudah menerima informasi lalu membagikan tanpa menyaring terlebih dahulu kebenarannya.

Peneliti memilih penelitian ini, untuk menjelaskan berbagai macam bentuk afiksasi serta kesalahan dalam proses pembentukannya dalam Laporan Isu Hoaks Corona Virus oleh KOMINFO. Hal ini dikarenakan banyak sekali isu-isu kabar hoaks yang beredar seiring dengan munculnya virus corona atau covid-19. Beberapa informasi yang dianggap tidak masuk akal namun tetap dipercayai oleh sebagian orang. KOMINFO merekap informasi tersebut dalam bentuk laporan beserta penjelasan kebenarannya. Akan tetapi, di dalam rekapan tersebut masih terdapat banyak kesalahan afiksasi, sehingga ada beberapa kalimat yang dianggap rancu bahkan memiliki makna lain. Kesalahan afiksasi yang dianggap biasa juga tidak dapat dibiarkan, karena jika dilihat secara sekilas kesalahan tersebut tidak terlihat. Padahal hal itu penting untuk diperhatikan, mengingat banyak pembaca yang tertarik dengan penjelasan alasan mengapa isu-isu hoaks virus corona atau covid-19 banyak terjadi dan bagaimana penjelasan kebenaran dari informasi hoaks tersebut.

Beberapa penelitian terdahulu yang meneliti tentang kesalahan berbahasa bidang morfologi pada proses afiksasi, yakni Pinem dan Lubis (2017) dengan judul Analisis Kesalahan Berbahasa dalam Tataran Morfologi pada Teks Deskripsi Siswa kelas VII SMP Negeri 40 Medan, dalam penelitiannya mereka meneliti kesalahan berbahasa yang dilakukan oleh siswa dan menyimpulkan bahwa kesalahan berbahasa yang banyak dilakukan siswa pada proses afiksasi adalah penulisan prefiks. Penelitian lainnya dilakukan oleh Maesaroh (2016) dengan judul Analisis Kesalahan Bidang Morfologi pada Karangan Deskriptif Siswa SMA, dalam penelitiannya juga mengkaji tentang kesalahan yang terdapat dalam tulisan hasil siswa pada tingkat SMA yang meliputi kesalahan proses afiksasi. Selain dua penelitian di atas, ada juga penelitian yang dilakuka oleh Sintia, Sudiana, dan Nurjaya (2019) yang berjudul Analisis Kesalahan Morfologi Pada Tuturan Siswa SMP N 3 Banjar dalam penelitian tersebut peneliti meneliti tentang kesalahan tuturan dari sebelas bentuk kesalahan afiksasi. Peneliti hanya menemukan data tuturan siswa yang menggunakan kata majemuk dengan benar karena siswa sudah mampu untuk menggunakan kata majemuk dengan tepat. Ketiga peneliti tersebut sama-sama meneliti tentang kesalahan berbahasa Perbedaan dengan penelitian ini, yakni terletak pada sumber data penelitian yang dianalisis, peneliti lain meneliti hasil tulisan siswa sekolah menengah sedangkan pada penelitian ini berdasar pada hasil laporan oleh KOMINFO dengan fokus penelitian proses afiksasi. Penelitian ini bertujuan sebagai analisis dan penilaian terhadap 
Agus Tika Dwi Savira, Sarifah Firda Arindita Nafarin, dan Siti Nur Fa'izah

kesalahan bentuk afiksasi pada Laporan Isu Hoaks Corona Virus oleh KOMINFO serta informasi tentang pembenaran proses afiksasi tersebut.

\section{METODE}

Penelitian ini menggunakan metode pendekatan deskriptif kualitatif. Penelitian kualitatif merupakan penelitian yang menghasilkan data berupa pendeskripsian kata baik tertulis maupun lisan dari orang atau perilaku yang diamati. Menurut Bachri (2010), penelitian kualitatif ditujukan untuk mendeskripsikan sebuah analisis mengenai fenomena, peristiwa, aktivitas sosial, kepercayaan, sikap, persepsi, atau mengenai pemikiran seseorang terhadap suatu permasalahan. Deskripsi tersebut dapat digunakan untuk menemukan prinsip-prinsip dan penjelasan guna penarikan kesimpulan. Jenis penelitian yang digunakan yaitu studi kasus, dengan tujuan untuk mendeskripsikan kesalahan morfologi dengan objek kajian yaitu Laporan Isu Hoaks Corona Virus yang terbit pada tanggal 17 Maret 2020 pada pukul 08.00 WIB. Objek penelitan ini adalah beberapa bentuk morfem yang mengalami kesalahan afiksasi. Penelitian ini difokuskan pada satu masalah yaitu kesalahan berbahasa yang ditinjau dari bentuk kesalahan proses afiksasi.

Data dikumpulkan dengan menggunakan metode simak, catat, dan pengambilan sampel. Menurut Priyono (2012), metode simak dan catat dilakukan dengan menyimak objek secara seksama untuk diklasifikasikan sebagai sampel. Dalam pengambilan sampel peneliti sebagai instrumen kunci yang melakukan aktivitas simak dan catat terhadap data. Penyimakan harus dilakukan secara cermat, teliti, terarah, dan terpadu sesuai dengan tujuan penilitian. Dari hasil simak dan catat dapat disimpulkan sampel yang layak untuk dijadikan sebagai objek analisis data. Metode analisis data yang digunakan berupa metode agih. Menurut Sudaryanto (1993: 15), metode agih merupakan metode yang menggunakan alat penentu bagian dari bahasa yang bersangkutan untuk menjadi objek sasaran dalam penelitian itu sendiri. Dengan adanya penelitian ini, diharapkan pembaca dapat mengetahui lebih dalam tentang kesalahan berbahasa dalam bidang morfologi terutama proses afiksasi.

\section{HASIL DAN PEMBAHASAN}

Berdasarkan penelitian yang telah dilakukan, peneliti menemukan berbagai macam kesalahan berbahasa bidang morfologi yaitu prefiks, sufiks, dan konfiks. Akan tetapi, tidak ditemukan kesalahan berbahasa bidang morfologi lain, yaitu infiks. Kesalahan paling banyak terjadi pada bagian konfiks dan sufiks, sedangkan bagian prefiks hanya terdapat 
Agus Tika Dwi Savira, Sarifah Firda Arindita Nafarin, dan Siti Nur Fa'izah

beberapa saja. Selanjutnya, akan disebutkan berapa jumlah kesalahan pada masingmasing bagian sekaligus menjelaskan bentuk kesalahannya.

\begin{tabular}{lll}
\hline Kesalahan & Jenis Kesalahan & Jumlah \\
\hline Kesalahan Afiksasi & Penghilangan Afiks me $(N)$ & 5 Kesalahan \\
& Penghilangan Afiks ber- & 2 Kesalahan \\
& Penghilangan Afiks di- & 1 Kesalahan \\
Kesalahan Sufiks & Penghilangan Sufiks -an & 2 kesalahan \\
& $\begin{array}{l}\text { Penghilangan Sufiks -kan } \\
\text { Kesalahan Konfiks }\end{array}$ & 4 kesalahan \\
& $\begin{array}{l}\text { Kesalahan penulisan konfiks ber-an } \\
\text { an, me }(N) \text {-an dan ber-an }\end{array}$ & 1 kesalahan \\
& $\begin{array}{l}\text { Kesalahan penggunaan bentuk kata } \\
\text { dasar }\end{array}$ & 5 Kesalahan \\
& $\begin{array}{l}\text { Kesalahan peluluhan bunyi dalam } \\
\text { konfiks }\end{array}$ & 2 Kesalahan \\
\hline
\end{tabular}

Tabel 1. Data Hasil Temuan kesalahan

\section{KESALAHAN PREFIKS}

Salah satu bentuk kesalahan morfologi dalam artikel tersebut ialah kesalahan prefiksasi. Prefiksasi merupakan proses pembentukan kata dengan penambahan imbuhan di awal bentuk kata dasar yang disebut dengan afiks (Strazny, 2005). Oleh karena itu, menimbulkan fungsi kedudukan dan makna baru yang relevan. Jika di padukan dalam sebuah kalimat, maka kata tersebut akan menjadi satu kesatuan yang utuh. Terdapat 8 kesalahan bentuk prefiksasi yang terbagi menjadi 3 macam, yaitu:

\section{Penghilangan Afiks $m e(N)$ -}

Kata tersebut antara lain ialah jalani, hilangkan, ubah, cegah, kurangi dan obati. Berdasarkan hubungan korelasi kalimat, penggunaan kata tersebut perlu diberi afiks $m e(N)$ - di awal kata agar lebih padu.

Bentuk Kesalahan:

Data (1), "Menteri Nadien positif virus corona, Jalani isolasi secara mandiri,..."

Data (2), "Berkumur air hangat dengan garam dan cuka bisa hilangkan virus 
corona"

Data (3), "Pasar Tanah Abang tutup sementara untuk cegah corona."

Data (4), "...bahwa urin dan kotoran sapi bisa obati penyakit virus corona 2019."

Data (5), "Minum alkohol bisa kurangi risiko terkena Corona."

Penggunaan kata jalani pada data (1) kurang tepat karena perlu penegasan berupa kata kerja yang menyatakan tindakan. Kata jalani akan menjadi lebih tepat jika dilekatkan dengan afiks me $(N)$ - sehingga menjadi $(m e(N)+$ jalani). Menjalani merupakan bentuk kata verba yang berarti upaya untuk menempuh, melakukan atau melewati masa, waktu dan keadaan tertentu sehingga kalimat tersebut akan menjadi lebih padu apabila kata jalani mengalami prefiksasi menjadi kata menjalani.

Sama halnya dengan data (2) pada kata hilangkan dalam kalimat tersebut mengalami penghilangan afiks me $(N)$ - Pelepasan morfem terikat tersebut menyebabkan kalimat menjadi rancu bagi pembaca. Akan menjadi lebih padu apabila kata hilangkan disandingkan dengan bentuk alomorf meng-, sehingga menjadi (meng + hilangkan). Proses prefiksasi tersebut menghasilkan perubahan kata hilangkan menjadi menghilangkan.

Pemberian imbuhan bentuk alomorf tidak hanya terjadi pada data (2) saja, tetapi juga data (3), (4) dan (5). Kata obati pada data (4) mengalami prefiksasi bentuk alomorf (meng + obati) sehingga menjadi kata mengobati, sedangkan kata cegah pada data (3) mengalami prefiksasi me(N)-, (men + cegah), sehingga menjadi bentuk kata verba mencegah. Lalu, dada yang sedikit berbeda dengan data-data tersebut, yakni data (5) mengalami peluruhan fonem $/ \mathrm{k} /$, sehingga terjadi peleburan dalam proses afiksasi. Prefiksasi tersebut dari kata kurangi yang mendapatkan afiks (meng + kurangi) sehingga menjadi kata mengurangi. Tidak semua fonem mengalami peleburan, hanya beberapa fonem saja seperti /k/, /p/, /s/ dan /t/.

Kalimat yang tepat yaitu:

Data (1), "Menteri Nadien positif virus corona, menjalani isolasi secara mandiri,...".

Data (2), "Berkumur air hangat dengan garam dan cuka bisa hilangkan virus corona"

Data (3), "Pasar Tanah Abang tutup sementara untuk cegah corona."

Data (4), “...bahwa urin dan kotoran sapi bisa obati penyakit virus corona 2019."

Data (5), "Minum alkohol bisa kurangi risiko terkena Corona."

\section{Penghilangan Afiks ber-}

Bentuk Kesalahan:

Data (6), “...di Kota Depok terdapat pasien status Pasien Dalam Pengawasan $(P D P) \ldots "$

Data (7), “...semua aktivitas di Bali karena kaitan dengan hari raya Nyepi...”

Pada sampel data di atas mengalami penghilangan prefiks ber-, yang membuat kalimat menjadi kurang tepat. Afiks ber-merupakan prefiks pembentuk kata verba yang 
Agus Tika Dwi Savira, Sarifah Firda Arindita Nafarin, dan Siti Nur Fa'izah

menyatakan keberadaan seseorang dalam satu situasi, sehingga pada data (6) seharusnya mengalami prefiksasi (ber + status) yang akan menjadi kata berstatus. “...di Kota Depok terdapat pasien berstatus Pasien Dalam Pengawasan (PDP)...".

Begitupula dengan data (7), pada kata kaitan seharusnya mendapatkan afiks ber, (ber + kaitan) sehingga menjadi kata berkaitan. Berkaitan merupakan kata verba yang bermakna saling mengait atau saling bersangkutan. Kalimat perbaikan tersebut menjadi “...semua aktivitas di Bali karena berkaitan dengan hari raya Nyepi...”. Kalimat tersebut lebih baik dari kalimat sebelumnya yang belum melalui proses afiksasi karena pada kalimat tersebut memiliki hubungan keterkaitan antara diberhentikannya semua aktivitas di Bali dengan perayaan hari raya nyepi. Kalimat yang tepat sebagai berikut.

Data (6), “...di Kota Depok terdapat pasien berstatus Pasien Dalam Pengawasan $(P D P) \ldots "$

Data (7), "...semua aktivitas di Bali karena berkaitan dengan hari raya Nyepi..."

\section{Penghilangan Afiks di-}

Data (8), "Pasar Tanah Abang tutup sementara untuk cegah corona."

Pada data (8) kesalahan prefiksasi terjadi karena hilangnya afiks di- pada kata tutup. Afiks di- merupakan prefiks pembentuk kata verba yang lazim dikenai tindakan. Kata tutup merupakan bentuk verba nomina yang diartikan sebagai sebuah benda yang menjadi alat untuk membatasi sesuatu sehingga tidak terlihat isinya. Sedangkan kata tutup pada data (8) adalah sesuatu yang melibatkan objek lain sehingga lebih baik diberi imbuhan afiks (di-), (di + tutup) yang menjadi kata ditutup. Kalimat yang tepat sebagai berikut.

Data (8), "Pasar Tanah Abang ditutup sementara untuk cegah corona."

\section{KESALAHAN SUFIKS}

Kesalahan afiksasi berikutnya adalah kesalahan penambahan dan ketidaktepatan penggunaan sufiks. Dalam penelitian ini, terdapat 12 data yang dibagi dalam 3 macam kesalahan, yaitu: (1) penghilangan sufiks -an, (2) penghilangan sufiks -kan, dan (3) penghilangan sufiks -nya.

\section{Penghilangan Sufiks -an}

Bentuk kesalahan:

Data (1) ... Ronaldo belum pernah memberi pernyataan akan menjadikan hotel mewahnya sebagai rumah sakit ...

Data (2) ... dengan mengubah tanggal posting beserta isinya yang seolah-olah postingan tersebut sudah lama dibuat ...

Sufiks -an tidak mempunyai bentuk variasi dalam artian bentuk manapun tetap memiliki imbuhan -an, pemberian imbuhan dilakukan dengan cara merangkai ke dalam 
kata yang diimbuhinya. Pada data (1), berasal dari kata dasar beri yang merupakan kata kerja kemudian mendapat prefiks me-sehingga menjadi memberi. Kata tersebut tidak sesuai dengan kata yang dimaksud, seharusnya kata tersebut mendapatkan sufiks -an yang berubah menjadi memberikan. Begitu pun pada data (2), kata posting merupakan sebuah kata asing yang memiliki arti sama dengan kata dasar unggah yang berupa kata kerja, namun kata tersebut kurang sesuai digunakan dalam kalimat tersebut, dengan adanya sufiks -an maka kata dalam kalimat tersebut akan berubah menjadi unggahan yang merupakan kalimat baku. Kalimat yang tepat sebagai berikut.

Data (1) ... Ronaldo belum pernah memberikan pernyataan akan menjadikan hotel mewahnya sebagai rumah sakit ...

Data (2) ... dengan mengubah tanggal unggahan beserta isinya yang seolah-olah postingan tersebut sudah lama dibuat ...

\section{Penghilangan Sufiks -kan}

Bentuk kesalahan:

Data (3) Menurut kepala kantor perwakilan kemenkumham Sultra, Sofyan, berdasar surat sertifikat kesehatan Thailand

Data (4) ... keberhasilan serum Palestina yang diberi kepada Dr.Manar Saadi, Al shenawi

Data (5) CNN Internasional melalui akun Twitternya juga menginformasi bahwa tidak ada bukti bahwa Colloidal Silver atau koloid perak dapat melindungi kita dari virus Corona

Data (6) Dari jumlah warga tersebut ada warga Pamekasan, sedang di Pamekasan

sendiri belum pernah ada kasus pasien tersuspect virus Corona.

Sufiks -kan tidak mengalami perubahan bentuk dalam penggabungannya, jadi untuk situasi dan kondisi apapun bentuknya tetap sama. Pemberian imbuhan dilakukan dengan cara merangkainya di akhir kalimat. Pada data (3), data (4), dan data (5) kesalahan tersebut tidak sesuai dengan kalimat yang digunakan kata berdasar berasal dari kata dasar, kata diberi berasal dari kata beri dan kata menginformasikan berasal dari kata informasi. Di mana ketiga kata tersebut merupakan sebuah kata kerja yang kemudian mendapat prefiks ber-pada kata dasar dan prefiks $d i$ - pada kata beri dan prefiks meng-pada kata menginformasi.

Kata dasar tidak sesuai dengan kalimat yang digunakan, seharusnya kata tersebut mendapatkan sufiks -kan yang berubah menjadi berdasarkan yang menunjukkan sebuah pernyataan. Kata beri yang telah mendapat prefiks di-juga tidak sesuai dengan kalimatnya karena seharusnya kata tersebut mendapat imbuhan -kan diberikan agar menjadi kalimat pernyataan yang sesuai dengan konteks kalimatnya. Sedangkan kata informasi telah mendapatkan prefiks meng- yang berubah menjadi menginformasi di mana kata tersebut kurang menunjukkan sebuah pernyataan, agar kata tersebut menjunjukkan sebuah pernyataan maka kata tersebut harus mendapatkan sufiks -kan yang akan berubah menjadi menginformasikan. 
Agus Tika Dwi Savira, Sarifah Firda Arindita Nafarin, dan Siti Nur Fa'izah

Pada data (6) kesalahan ada dalam kata sedang yang merupakan kata keterangan dan sebelum kata sedang ada kalimat pernyataan yang bersifat membandingkan dengan kalimat setelahnya. Oleh karena itu, kata sedang harus mendapatkan sufiks -kan agar menjadi kata banding antar kalimat. Jadi, kata sedang pembenarannya adalah sedangkan. Kalimat yang tepat sebagai berikut.

Data (3) Menurut kepala kantor perwakilan kemenkumham Sultra, Sofyan, berdasarkan surat sertifikat kesehatan Thailand

Data (4) ... keberhasilan serum Palestina yang diberikan kepada Dr.Manar Saadi, Al-shenawi

Data (5) CNN Internasional melalui akun Twitternya juga menginformasikan bahwa tidak ada bukti bahwa Colloidal Silver atau koloid perak dapat melindungi kita dari virus Corona

Data (6) Dari jumlah warga tersebut ada warga Pamekasan, sedangkan di Pamekasan sendiri belum pernah ada kasus pasien tersuspect virus Corona.

\section{Penghilangan sufiks - nya}

Bentuk kesalahan:

Data (7) la mengatakan bahwa Mendagri dan istri dalam keadaan sehat

Data (8) Melalui akun instagram resmi kasablanka, manajemen menegaskan kabar itu hoaks

Data (9) Sekretaris Desa Kaliajir mengatakan jika di Desa Kaliajir tidak ada RW 05 dan tidak ada warga yang baru pulang dari luar negeri.

Data (10) Dalam pesan disebutkan bahwa pasien berobat ke RS Siloam dan dipindahkan ke AR Bunda

Data (11) Rumah Sakit Johanes kupang membuat klarifikasi yang mengatakan bahwa ada pasien positif covid-19 di RSUD Johannes Kupang itu tidak benar

Data (12) pihak RSUP Adam Malik Medan membantah ada seorang warga berasal dari Kota Padang Sidempuan, Sumatera Utara terinfeksi Virus Corona

Sufiks -nya membentuk suatu kata kerja pasif. Penggunaannya sebagai sufiks yang dilafalkan dan dituliskan dengan cara dirangkai dengan kata yang dibubuhinya. Pada data (7), data (8), data (9), dan data (10) merupakan sebuah kata dasar yang menunjukkan kepunyaannya atau kepemilikan. Data (7) kata istri merupakan sebuah kata kerja yang mendapatkan imbuhan -nya sehingga menunjukkan sebagai kepemilikan karena sebelum kata istri terdapat kata Mendagri dan istri, jadi kata istri berubah menjadi kata istrinya agar menunjukkan milik Mendagri. Data (8) agar kalimat itu jelas dengan adanya pernyataan maka kata manajemen yang merupakan kata kerja harus mendapat imbuhan -nya agar memperjelas kalimat pertamanya dimana kata manajemen dirubah menjadi manajemennya. Data (9) kata warga merupakan kata kerja yang berubah makna menjadi kata kepemilikan, di mana warga pada konteks kalimat tersebut merupakan kepemilikan dari RT setempat untuk merubah kata kerja menjadi kepemilikan harus ada penambahan sufiks -nya maka kata warga akan berubah menjadi kata warganya. Pada data (10) kata pesan belum menunjukkan suatu pernyataan yang jelas dan masih terkesan rancu. Supaya menjadi kalimat pernyataan, 
kata tersebut harus mendapatkan sufiks -nya maka kata pesan akan berubah menjadi kata berpesan.

Pada data (11) dan data (12) merupakan sebuah kata kerja yang akan berubah menjadi sebuah pernyataan atau penegasan, untuk mengubah kata kerja tersebut perlu adanya penambahan imbuhan - nya pada setiap pernyataan. Seperti pada kata ada mendapatkan imbuhan -nya karena akan berubah menjadi adanya. Kalimat yang tepat sebagai berikut.

Data (7) la mengatakan bahwa Mendagri dan istrinya dalam keadaan sehat

Data (8) Melalui akun instagram resmi kasablanka, manajemennya menegaskan kabar itu hoaks

Data (9) Sekretaris Desa Kaliajir mengatakan jika di Desa Kaliajir tidak ada RW 05 dan tidak ada warganya yang baru pulang dari luar negeri.

Data (10) Dalam pesannya disebutkan bahwa pasien berobat ke RS Siloam dan dipindahkan ke AR Bunda

Data (11) Rumah Sakit Johanes kupang membuat klarifikasi yang mengatakan bahwa adanya pasien positif covid-19 di RSUD Johannes Kupang itu tidak benar

Data (12) pihak RSUP Adam Malik Medan membantah adanya seorang warga berasal dari Kota Padang Sidempuan, Sumatera Utara terinfeksi Virus Corona

\section{KESALAHAN KONFIKS}

Kesalahan morfologi selanjutnya adalah kesalahan konfiks. Konfiks merupakan gabungan dari prefiks dan sufiks yang biasanya berada di antara kata dasar. Dalam penelitian ini, terdapat 12 data yang diklasifikasikan menjadi 4 macam kesalahan konfiks yaitu (1) kesalahan penulisan konfiks ber-an, (2) pemakaian konfiks pe(N)-an, $m e(N)$-an dan ber-an, (3) kesalahan penggunaan bentuk kata dasar, dan (4) kesalahan peluluhan bunyi dalam konfiks.

\section{Kesalahan Penulisan Konfiks ber-an}

Bentuk kesalahan:

Data (1), ...gerombolan burung gagak dan nyamuk berterbangan serta orang yang berlarian.

Penggunaan kata berterbangan merupakan kesalahan konfiks penulisan ber-an.

Dari kata dasar terbang yang mendapatkan imbuhan ber-an. Ketika prefiks berbertemu kata dasar pertama yang mengandung unsur er- maka seharusnya huruf $r$ pada prefiks ber-mengalami peluluhan. Kalimat yang tepat sebagai berikut.

Data (1), ...gerombolan burung gagak dan nyamuk beterbangan serta orang yang berlarian.

\section{Pemakaian Konfiks pe(N)-an, me(N)-an dan ber-an}

Bentuk kesalahan:

Data (2), ...pencegahan dini atau langkah antisipasi oleh perusahaan terhadap virus corona.

Data (3), . ...sebuah pesan WhatsApp informasi terkait kedatangan seorang pasien suspect virus corona...

Data (4), ...sebuah video ribuan burung gagak yang terbang dilangit kota Wuhan.

Data (5), ...mendatangi rumah warga dengan alasan program pemerintah untuk semprot kuman agar steril. 
Pada data (2) dan (5) seharusnya menggunakan konfiks pe(N)-an agar sesuai kaidah kebahasaan yang benar. Penggalan kalimat yang ada membahas tentang langkah atau proses melakukan sesuatu, sehingg kata antisipasi yang berarti perhitungan akan hal yang belum terjadi seharusnya diubah menjadi pengantisipasian yang memiliki arti proses atau cara mengantisipasi. Begitupun kata semprot yang berarti alat untuk menyemprotkan air sebaiknya diubah menjadi penyemprotan yang berarti proses atau cara menyemprot.

Pada data (3), seharusnya menggunakan konfiks me(N)-an, sehingga kata informasi yang berarti pemberitahuan diubah menjadi menginformasikan yang berarti memberikan informasi agar membentuk kata kerja yang sesuai. Sama hal nya pada data (4), kata terbang yang seharusnya menjadi kata beterbangan. Dikarenakan pada beberapa kata benda ketika mendapatkam imbuhan, maka kata tersebut bias berubah menjadi kata kerja. Kalimat yang tepat sebagai berikut.

Data (2), ...pencegahan dini atau langkah pengantisipasian oleh perusahaan terhadap virus corona.

Data (3), ...sebuah pesan WhatsApp menginformasikan terkait kedatangan seorang pasien suspect virus corona...

Data (4), ...sebuah video ribuan burung gagak yang beterbangan dilangit Kota Wuhan.

Data (5), ...mendatangi rumah warga dengan alasan program pemerintah untuk penyemprotan kuman agar steril.

\section{Kesalahan Penggunaan Bentuk Kata Dasar}

Bentuk kesalahan:

Data (6), Namun setelah dilakukan perawatan, pasien tersebut tidak terbukti terpapar virus corona.

Data (7), Diketemukan video yang sama di YouTube pada tanggal 28 November 2019, sebulan sebelum wabah virus corona menyebar.

Data (8), ...dengan mengambil langkah-langkah pencegahan proaktif untuk mencegah kedatangan virus corona baru...

Data (9), Telah beredar di media sosial Facebook sebuah video dengan 3 jenazah yang diringkas dalam 1 kantong mayat...

Data (10), Karolin juga memaparkan mahasiswa tersebut memang kurang sehat dan suhunya panas.

Kesalahan bentuk kata dasar ini biasanya terjadi karena kekeliruan pada saat pemilihan kata setelah diberi imbuhan, sehingga menimbulkan makna yang berbeda.

Pada data (6), kata dasar rawat berarti jaga. Tidak sesuai dengan kalimat dimaksud yang bermakna melakukan pengamatan, sehingga kata dasar yang cocok yaitu periksa dan setelah mendapatkan konfiks pe-an menjadi pemeriksaan. Selanjutnya pada data (7), kata dasar yang benar yaitu temu bukan ketemu, sehingga pada saat mendapatkan konfiks di-kan menjadi ditemukan.

Begitupun pada data (8), kata datang yang identik dengan sampainya seseorang bukan penyakit karena penyakit biasanya ditularkan, sehingga kata yang benar adalah 
penularan yang berasal dari kata dasar tular kemudian mendapatkan imbuhan pe(N)an. Pada data (9) juga terdapat kesalahan dalam kata diringkas yang seharusnya identik dengan barang bukan manusia, sehingga kata yang lebih tepat yaitu memasukkan, berasa; dari kata dasar masuk kemudian mendapatkan konfiks me-kan. Terakhir pada data (10), terdapat kata memaparkan yang dirasa kurang tepat. Sebaiknya kata yang digunakan yaitu menjelaskan. Kalimat yang tepat sebagai berikut.

Data (6), Namun setelah dilakukan pemeriksaan, pasien tersebut tidak terbukti terpapar virus corona.

Data (7), Ditemukan video yang sama di YouTube pada tanggal 28 November, sebulan sebelum wabah virus corona menyebar.

Data (8), ...dengan mengambil langkah-langkah pencegahan proaktif untuk mencegah penularan virus corona baru...

Data (9), Telah beredar di media sosial Facebook sebuah video dengan 3 jenazah yang dimasukkan dalam 1 kantong mayat...

Data (10), Karolin juga menjelaskan mahasiswa tersebut memang kurang sehat dan suhunya panas.

\section{Kesalahan Peluluhan Bunyi dalam Konfiks}

Bentuk kesalahan:

Data (11), Adapun, sebagai upaya menghindari Virus Corona Kemenkes tengah mensosialisasikan program GERMAS.

Data (12), ...seorang perempuan memperagakan penggunaan tisu basah sebagai pengganti masker.

Peluluhan fonem biasa terjadi ketika sebuah fonem digantikan oleh fonem lain karena adanya proses setelah pengimbuhan. Terdapat dua kesalahan pada saat peluluhan fonem pada data (11) dan (12). Kesalahan ini dikarenakan huruf awalan pada kata dasar yang dicetak tebal sehar usnya diluluhkan. Kata dasar yang memiliki huruf awalan $k, p, s$ dan $t$ ketika mendapatkan imbuhan me $(N)$ - dan $p e(N)$ - maka harus diluluhkan, sehingga kata mensosialisasikan diubah menjadi menyosialisasikan dan kata memperagakan diubah menjadi memeragakan. Kalimat yang tepat sebagai berikut.

Data (11), Adapun, sebagai upaya menghindari Virus Corona Kemenkes tengah menyosialisasikan program GERMAS.

Data (12), ...seorang perempuan memeragakan penggunaan tisu basah sebagai pengganti masker.

\section{SIMPULAN}

Berdasarkan uraian di atas ditemukan bahwa, terdapat tiga kesalahan morfologi. Pertama, kesalahan proses afikasi yang ditemukan meliputi delapan kesalahan bentuk prefiksasi, yang terbagi menjadi tiga macam, yaitu: (1) penghilangan afiks me(N) antaranya: jalani, hilangkan, ubah, cegah, kurangi dan juga obati. (2) penghilangan afiks ber- antaranya: status, kaitan. dan (3) penghilangan afiks di- antaranya: tutup. Kedua, ada dua belas data yang dibagi dalam tiga macam kesalahan, antara lain: (1) 
penghilangan sufiks -an antaranya: memberi dan juga posting (2) penghilangan sufiks -kan antaranya: berdasar, diberi, menginformasi, sedang, dan (3) penghilangan sufiks -nya antaranya: istri, manajemen, warga, pesan, ada. Ketiga, kesalahan pada konfiks ditemukan dua belas kesalahan, yang dibagi ke dalam empat macam kesalahan konfiks, yaitu (1) kesalahan penulisan konfiks ber-an antaranya: terbang, (2) pemakaian konfiks pe(N)-an, me(N)-an dan ber-an antaranya: antisipasi, informasi, terbang, dan semprot, (3) kesalahan penggunaan bentuk kata dasar antaranya: perawatan, diketemukan, kedatangan, diringkas, dan memaparkan, serta (4) kesalahan peluluhan bunyi dalam konfiks antaranya: mensosialisasikan dan memperagakan.

Kesalahan-kesalahan tersebut lazim terjadi dalam bidang linguistik. Seperti pada penelitian ini yang masih memiliki banyak terdapat kesalahan morfologi. Pada laporan berita tersebut terdapat beberapa kata yang kurang tepat. Hal tersebut disebabkan oleh proses pembentukan kata yang tidak sesuai dengan konteks kalimat yang digunakan, sehingga menyebabkan multitafsir oleh pembaca. Hal ini mengakibatkan munculnya informasi baru yang tidak sesuai dengan informasi sebenarnya atau berita bohong (hoaks).

\section{DAFTAR RUJUKAN}

Astuti, E. P. 2012. Analisis Afiksasi dan Penghilangan Bunyi pada Lirik Lagu Geisha dalam Album Meraih Bintang. Universitas Muhammadiyah Surakarta.

Bachri, B. S. 2010. Meyakinkan Validitas Data melalui Trianggulasi pada Penelitian Kualitatif. Jurnal Teknologi Pendidikan, 10(1), 46-62.

Chaer, A. 2012. Linguistik Umum (Edisi Baru). Jakarta: Rineka Cipta.

Johan, G. M. 2018. Analisis Kesalahan Berbahasa Indonesia Dalam Proses Diskusi Siswa Sekolah Dasar. Jurnal Pendidikan Bahasa Dan Sastra Indonesia, 18(1), 136-149.

Maesaroh, Siti. 2016. Analisis Kesalahan Bidang Morfologi pada Karangan Deskriptif Siswa SMA. Universitas Muhammadiyah Surakarta.

Malik, A. R., \& Fatimah, S. 2017. Analisis Kesalahan Morfologi dalam Karangan Sederhana Bahasa Jerman Siswa Kelas XI SMAN 2 Makassar. Eralingua, 1(1).

Nurwicaksono, B. D., \& Amalia, D. 2018. Analisis Kesalahan Berbahasa Indonesia pada Teks IImiah Mahasiswa. AKSIS Jurnal Pendidikan Bahasa Dan Sastra Indonesia, 2(2), 138-153.

Permatasari, Nanda Putri. 2013. Abreviasi, Afiksasi, dan Reduplikasi Ragam Bahasa Remaja dalam Media Sosial Facebook. Jurnal Sastra Indonesia. FIB UNDIP.

Pinem, D., \& Lubis, F. 2017. Analisis Kesalahan Berbahasa dalam Tataran Morfologi pada Teks Deskripsi Siswa Kelas VII SMP Negeri 40 Medan Tahun Pembelajaran 2016/2017. Kode:Jurnal Bahasa, 1-14.

Priyono, Y. 2012. Analisis Kesalahan Berbahasa Bidang Morfologi pada Mading di Unversitas Muhammadiyah Surakarta. Universitas Muhammadiyah Surakarta.

Sintia, M., Sudiana, I. N., \& Nurjaya, I. G. 2019. Analisis Kesalahan Morfologi pada 
Tuturan Siswa SMP N 3 Banjar. Jurnal Pendidikan Bahasa Dan Sastra Indonesia UNDIKSHA, 9(2), 204-215.

Strazny, P. 2005. Encyclopedia of Linguistic Volume 1. NewYork: Fitzroy Dearborn.

Sudaryanto. 1993. Metode dan Aneka Teknik Analisis Bahasa. Yogyakarta: Duta Wacana University Press.

Verawati, F., \& Mulyadi. 2019. Tindak Tutur Masyarakat di Desa Lawangan Daya Kecamatan Pademawu Kabupaten Pamekasan. GHANCARAN, 1(1), 41-51.

Yuliana. (2020). Corona Virus Diseases (Covid-19); Sebuah Tinjauan Literatur. Wellness And Healthy Magazine, 2(1), 187-192. 